\title{
A Study of Angiotensin II Pressor Response throughout Primigravid Pregnancy
}

\author{
Norman F. Gant, Gilroy L. Daley, Santosh Chand, Peggy J. Whalley, and \\ Paul C. MacDonald
}

From the Department of Obstetrics and Gynecology, The University of Texas

Southwestern Medical School at Dallas, Texas 75235

A в S T R A C T The present study was designed to ascertain sequentially the pressor response to angiotensin II in young primigravid patients throughout pregnancy in order $a$ ) to define when in pregnancy resistance to the pressor effects of angiotensin II develops; $b$ ) to define the physiologic sequence of events leading to this resistance; and $c$ ) to ascertain whether sensitivity to infused angiotensin II could be detected before the onset of clinical signs of pregnancy-induced hypertension.

With this prospective approach, two separate groups of patients were defined. The first group of patients remained normal throughout pregnancy. The second group consisted of those patients who, while clinically normotensive during the initial phase of the study, ultimately developed hypertension of pregnancy.

192 patients were studied; of these, 120 patients remained normotensive and 72 developed pregnancy-induced hypertension. In both groups, vascular resistance to infused angiotensin II (more than $8 \mathrm{ng} / \mathrm{kg} / \mathrm{min}$ required to elicit a pressor response of $20 \mathrm{~mm} \mathrm{Hg}$ in diastolic pressure) was demonstrated as early as the 10th wk of pregnancy. In the group that remained normotensive, maximum mean vascular resistance occurred at 18-30 wk of pregnancy, (mean pressor dose required being 13.5 to $14.9 \mathrm{ng} / \mathrm{kg} / \mathrm{min}$ ). In those subjects who developed pregnancy-induced hypertension, the mean maximum dose required was $12.9 \mathrm{ng} / \mathrm{kg} / \mathrm{min}$, which was observed at the 18 th wk of pregnancy. By the $22 \mathrm{nd}$ wk there was a clear separation of the two groups, with the mean dose requirement of the subjects destined to develop hypertension being progressively less than that of those who remained normal. The difference between the two groups became significant $(P<0.01)$ by $23-26$ wk of pregnancy.

Among patients requiring more than $8 \mathrm{ng} / \mathrm{kg} / \mathrm{min}$ on

Dr. Chand was a trainee during this study, and was supported by U.S.P.H.S. training grant 5-TO1, HD-00256.

Received for publication 15 February 1973 and in revised form 15 June 1973. one or more tests done between wk $28-32,91 \%$ remained normotensive. Conversely, during the same time period among patients requiring less than $8 \mathrm{ng} / \mathrm{kg} / \mathrm{min}$, on at least one occasion, $90 \%$ developed pregnancy-induced hypertension.

\section{INTRODUCTION}

Normal human pregnancy, compared to the nonpregnant state, is characterized by increased plasma renin concentration, renin activity, renin substrate, angiotensin II (A-II), ${ }^{1}$ and aldosterone (1-11). Elevated excretory and secretory rates of aldosterone also have been observed in normal pregnancy (12-18). Normal pregnant women are also known to be quite resistant to the pressor effects of infused A-II $(19,20)$. In contrast, pregnancies complicated by pregnancy-induced hypertension are associated wtih lowered levels of plasma renin concentration $(21,22)$, and plasma and urinary aldosterone (9, 13-15). Additionally, patients with pregnancy-induced hypertension are exquisitely sensitive to the pressor effects of A-II $(20,23)$, when compared to normotensive pregnant women.

The purpose of the present study was $a$ ) to ascertain when in the course of pregnancy pressor resistance to infused A-II develops; $b$ ) to define the normal physiologic sequence of event leading to this resistance; and c) to ascertain whether sensitivity to infused A-II could be detected before the onset of clinical signs of pregnancy-induced hypertension. To achieve these goals, a prospective study of the pressor response to infused A-II was performed sequentially at frequent intervals throughout the course of pregnancy in normal teenage primigravid girls. The results of $1200 \mathrm{~A}-\mathrm{II}$ infusions in 202 subjects (192 pregnant, 10 nonpregnant) constitue the data of this report. Two separate groups of pregnant

${ }^{1}$ Abbreviation used in this paper: A-II, angiotensin II. 
subjects were characterized. The first group consisted of those who remained normal throughout pregnancy. The second group consisted of those who, while clinically normal during the early phase of the study, ultimately developed clinical signs and symptoms of pregnancyinduced hypertension (preeclampsia) and in one instance, eclampsia.

The results of these studies confirm the findings of Abdul-Karim and Assali (19) that normal-term pregnant subjects are resistant to the pressor effects of injected A-II. The results of this study also show that the onset of this resistance occurs early and is maintained throughout pregnancy. However, at 30 wk of pregnancy in subjects who remain normal, a slight and continuing decrease in resistance to A-II is noted when compared to that resistance observed between 18-30 wk pregnancy. In those subjects who developed pregnancy-induced hypertension, the observations of Chesley (20) were confirmed, in that the subjects of this study with pregnancyinduced hypertension were exquisitely sensitive to infused A-II. Of principal importance, this prospective study has shown that decreasing resistance to A-II is found as early as $26 \mathrm{wk}$ of pregnancy, some $12-14 \mathrm{wk}$ before the onset of clinical signs of pregnancy-induced hypertension, in those subjects destined to develop the disorder.

\section{METHODS}

Normal primigravid subjects (13-17 yr old) were chosen randomly from the Parkland Memorial Hospital Obstetric Clinic. None of the patients included in this study had a past history of renal disease or a personal or family history of hypertension. Of the total patients studied, $21 \%$ were Caucasian and $79 \%$ were Negro. These young women were studied sequentially throughout their pregnancies, beginning as early as the 7th wk of pregnancy. Each girl was seen throughout the course of pregnancy at 1-2 wk intervals. At each visit her weight was recorded, her urine tested for protein, and the presence or absence of edema noted. In none of these subjects was an attempt made to alter sodium intake. All subjects ate diets of their own choice and of unknown sodium content.

10 nonpregnant preoperative gynecologic patients without renal disease or hypertension were chosen as nonpregnant controls. The dose of A-II required to elicit the pressor response was measured in all studies as described below.

Each patient was placed in the left lateral recumbent position, and a venipuncture was performed with a wingedtipped 19-gauge scalp vein apparatus to maintain a route for subsequent infusion of A-II (1-L-asparaginyl-5-L-valyl angiotensin octapeptide). ${ }^{3}$ Auscultatory blood pressure measurements utilizing the onset of the first (systolic) and fifth (diastolic) sounds of Korotkoff were taken at 5-min intervals until a constant baseline diastolic pressure had been established for at least $15 \mathrm{~min}$. In most instances, the mini-

\footnotetext{
${ }^{2}$ Informed consent for these studies was obtained from the patient or her parents or guardian.

${ }^{3}$ Hypertensin-Ciba, Ciba Pharmaceutical Co., Summit, N. J.
}

TABLE I

Individual Dose of A-II Required to Evoke a Pressor Response in 10 Nonpregnant Subjects

\begin{tabular}{ccccc}
\hline \multicolumn{2}{l}{ Patient } & Weight & \multicolumn{2}{c}{ Pressor dose } \\
\hline & & $k g$ & $n g / m i n$ & $n g / k g / m i n$ \\
1. R. R.* & 78.63 & 586 & 7.54 \\
2. M. B. & 58.15 & 586 & 10.07 \\
3. M. G. & 53.63 & 419 & 7.81 \\
4. M. J. & 55.68 & 214 & 3.84 \\
5. B. L. & 55.22 & 419 & 7.58 \\
6. R. D. & 44.65 & 299 & 6.69 \\
7. D. M. & 76.81 & 586 & 7.62 \\
8. R. W. & 59.77 & 586 & 9.80 \\
9. L. J. & 66.20 & 586 & 8.85 \\
10. L. S. & 54.54 & 210 & 3.85 \\
Mean \pm SEM & & & $7.35 \pm 0.067$ \\
\hline
\end{tabular}

* All subjects were less than_25 yr of age.

mal time required to establish baseline values was $25-30$ min. After the diastolic pressure became constant, an infusion of a solution containing $1 \mu \mathrm{g} \mathrm{A}-\mathrm{II} / \mathrm{ml}$ of $5 \%$ dextrose in water was begun. This solution was administered via a Harvard infusion pump " with small progressive increments in dose each 5 min until a rise in diastolic blood pressure of $20 \mathrm{~mm} \mathrm{Hg}$ was obtained. Pending confirmation, this was considered the dose required to elicit a response. To confirm this as the pressor dose, the infusion was discontinued and the blood pressure allowed to return to its baseline level. The infusion was then restarted at the previous level that had elicited the pressor response. A repeat increase of $20 \mathrm{~mm} \mathrm{Hg}$ diastolic was considered as confirmation of the pressor dose response. In the very rare (less than 1 in 50 tests) instances in which confirmation was not achieved, the entire test was repeated at the next highest level until both infusions elevated the diastolic blood pressure $20 \mathrm{~mm} \mathrm{Hg}$, and this was considered the pressor dose. The effective pressor dose was recorded as the nanograms of A-II infused per kilogram of body weight per minute $(\mathrm{ng} / \mathrm{kg} / \mathrm{min})$ required to elevate baseline diastolic blood pressure $20 \mathrm{~mm} \mathrm{Hg}$ on two occasions. Student's $t$ test was used in the statistical analysis of the data.

\section{RESULTS}

The angiotensin II doses required to elicit the pressor response in the nonpregnant subjects are shown in Table I. The mean dose required $( \pm \mathrm{SE})$ for these subjects was $7.35 \pm 0.67 \mathrm{ng} / \mathrm{kg} / \mathrm{min}$. This result is identical to the mean dose requirements reported by Kaplan and Silah, $7.4 \mathrm{ng} / \mathrm{kg} / \mathrm{min}$, in 18 normotensive nonpregnant subjects (24).

In the women who remained normal throughout pregnancy, the earliest studies were performed at 7-10 wk of pregnancy. At this early stage of pregnancy, the mean A-II dose required to evoke a pressor response was $8.6 \pm 0.76 \mathrm{ng} / \mathrm{kg} / \mathrm{min}$. The dose required increased until 28 wk pregnancy, as shown in Fig. 1. By this stage of

\footnotetext{
‘ Model 975, Harvard Apparatus Co., Inc., Millis, Mass.
} 


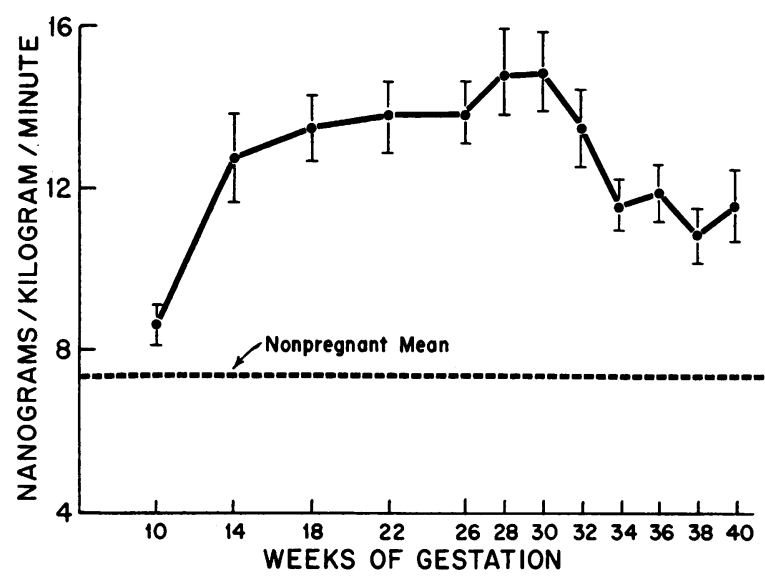

FIGURE 1 The mean A-II doses ( $\mathrm{ng} / \mathrm{kg} / \mathrm{min}$ ) required to evoke a pressor response in 120 primigravidas who remained normal throughout pregnancy (769 infusions). The nonpregnant mean is shown as a broken line. The horizontal bars represent the standard error of the mean.

pregnancy, the maximal resistance to A-II was observed, $(14.9 \pm 1.1 \mathrm{ng} / \mathrm{kg} / \mathrm{min})$. From $18 \mathrm{wk}$ pregnancy until approximately $30 \mathrm{wk}$, the pressor response remained markedly blunted, the mean dose ranging between 13.5$15.0 \mathrm{ng} / \mathrm{kg} / \mathrm{min}$. After $30 \mathrm{wk}$ there was the beginning of a small but continually decreasing resistance to A-II. The dose requirement fell to a mean of $10.7 \pm 0.71 \mathrm{ng} /$ $\mathrm{kg} / \mathrm{min}$ at $38 \mathrm{wk}$ of pregnancy. The number of tests, the dose requirements, means, and SEM are shown according to weeks of pregnancy in Table II.

72 of the subjects studied developed pregnancy-induced hypertension and one developed eclampsia. For the purpose of this study, pregnancy-induced hypertension is

TABLE II

Dose of A-II Required to Evoke a Pressor Response in 120 Primigravid Patients who Remained Normal throughout Pregnancy

\begin{tabular}{|c|c|c|}
\hline $\begin{array}{l}\text { Wk of } \\
\text { pregnancy }\end{array}$ & $\begin{array}{c}\text { Number of } \\
\text { determinations }\end{array}$ & $\begin{array}{c}\text { Mean pressor dose } \\
( \pm \text { SEM })\end{array}$ \\
\hline & & $n g / \mathrm{kg} / \min$ \\
\hline $7-10$ & 19 & $8.63 \pm 0.76$ \\
\hline $11-14$ & 31 & $12.78 \pm 1.11$ \\
\hline $15-18$ & 67 & $13.46 \pm 0.84$ \\
\hline $19-22$ & 75 & $13.83 \pm 0.90$ \\
\hline $23-26$ & 92 & $13.86 \pm 0.81$ \\
\hline $27-28$ & 53 & $14.9 \pm 1.10$ \\
\hline $29-30$ & 59 & $14.86 \pm 0.96$ \\
\hline $31-32$ & 70 & $13.50 \pm 0.95$ \\
\hline $33-34$ & 64 & $11.60 \pm 0.64$ \\
\hline $35-36$ & 75 & $11.87 \pm 0.71$ \\
\hline $37-38$ & 79 & $10.74 \pm 0.71$ \\
\hline $39-40$ & 85 & $11.61 \pm 0.88$ \\
\hline
\end{tabular}

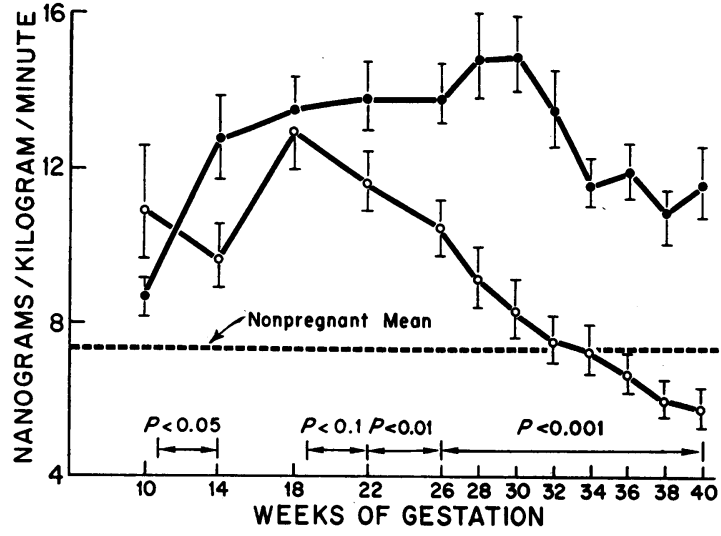

FIgURE 2 Comparison of the mean A-II doses (ng/kg/ min) required to evoke a pressor response in 120 primigravidas who remained normotensive and 72 primigravidas who ultimately developed pregnancy-induced hypertension. The nonpregnant mean is shown as a broken line. The horizontal bars represent the standard error of the mean. The black circles represent the results in 120 subjects who remained normal (769 infusions). The open circles represent the results obtained in 72 women who developed pregnancy-induced hypertension (421 infusions). The difference between the two groups became significant after wk 23 ( $P$ less than 0.01$)$ and the two groups continued to widely diverge after the 26th wk ( $P$ less than 0.001 ).

defined as $a$ ) the acute development of hypertension in a woman whose blood pressure was normal in the early stages of pregnancy and at $6 \mathrm{wk}$ postpartum and, $b$ ) the persistent elevation of blood pressure to at least 140/90, which must have represented an increase in the diastolic pressure of not less than $20 \mathrm{~mm} \mathrm{Hg}$ above previous pregnancy levels. Eclampsia is defined as the superimposition of grand mal seizures upon the above definition of hypertension.

Early in pregnancy, these 72 women also became very resistant to the pressor effects of infused A-II, just like those who remained normal. As graphically illustrated in Fig. 2, this resistance became maximal at 15-18 wk of pregnancy, the dose required being $12.9 \pm 1.1 \mathrm{ng} / \mathrm{kg} / \mathrm{min}$. However, from this early period of pregnancy forward, the resistance progressively decreased as pregnancy advanced. The difference between the pressor dose requirements of those subjects who remained normal and of those destined to develop pregnancy-induced hypertension was apparent by $22 \mathrm{wk}$ and became highly significant ( $P$ less than 0.01 ) by 23-26 wk. The difference between the groups became progressively widened thereafter. Even though both groups were clinically normal at 27-38 wk pregnancy, the difference in responsiveness to A-II was marked ( $P$ less than 0.001 ) as shown in Fig. 2. The early difference between the two groups of patients (Fig. 2) at 14 wk pregnancy can not at present be explained. The number of tests, dose requirements, and 
TABLE III

Dose of A-II Required to Evoke a Pressor Response in 72 Primigraid Patients who Ultimately Deieloped Pregnancy-Induced Hypertension

\begin{tabular}{rcc}
\hline $\begin{array}{c}\text { Wk of } \\
\text { pregnancy }\end{array}$ & $\begin{array}{c}\text { Number of } \\
\text { determinations }\end{array}$ & $\begin{array}{c}\text { Mean pressor dose } \\
( \pm \text { SEM })\end{array}$ \\
\hline & & $n g / k g / m i n$ \\
$7-10$ & 8 & $10.98 \pm 1.50$ \\
$11-14$ & 27 & $9.68 \pm 0.77$ \\
$15-18$ & 33 & $12.90 \pm 1.11$ \\
$19-22$ & 47 & $11.63 \pm 0.76$ \\
$23-26$ & 52 & $10.44 \pm 0.73$ \\
$27-28$ & 37 & $9.15 \pm 0.81$ \\
$29-30$ & 30 & $8.38 \pm 0.76$ \\
$31-32$ & 44 & $7.59 \pm 0.58$ \\
$33-34$ & 37 & $7.30 \pm 0.58$ \\
$* 35-36$ & 37 & $6.70 \pm 0.45$ \\
$\ddagger 37-38$ & 38 & $6.04 \pm 0.44$ \\
$\S 39-40$ & 31 & $5.82 \pm 0.44$ \\
\hline
\end{tabular}

* Three subjects hypertensive during this time period. $\ddagger$ Three additional subjects hypertensive during this time period.

$\S$ All subjects hypertensive by this time period.

SEM are tabulated by weeks of pregnancy for the group that developed pregnancy-induced hypertension and are shown in Table III.

The development of sensitivity to infused A-II in the subjects who developed hypertension was not preceeded by a significant increase in either systolic or diastolic blood pressures, as can be seen in Tables IV and V. The mean systolic blood pressures ranged between 106 and $107 \mathrm{~mm} \mathrm{Hg}$ in those women who remained normal, and between 107 and $113 \mathrm{~mm} \mathrm{Hg}$ in those subjects who later developed pregnancy-induced hypertension. Although the mean systolic blood pressure values are statistically different between the two groups very early and late in pregnancy, the values are not hypertensive; and in both groups of patients, the very early and late pregnancy values are almost identical. These early and late values in each group represent the well-known return of blood pressure from midpregnancy nadirs to early pregnancy or nonpregnant values.

The mean diastolic blood pressure values in both groups remained almost identical throughout pregnancy (Table V). The diastolic range for both groups of 50-64 $\mathrm{mm} \mathrm{Hg}$ is definitely not in the hypertensive range and is widely separated from the defined hypertensive value of $90 \mathrm{~mm} \mathrm{Hg}$.

It is important to note that between 23 and $32 \mathrm{wk}$ of pregnancy, at a time when sensitivity to A-II was increasing in women destined to become hypertensive, there was no significant edema noted and no albuminuria detected. However, excessive weight gain and edema did develop later in both normal and abnormal pregnancies, thus making this observation an extremely unreliable diagnostic and/or prognostic sign. The develop-

TABLE IV

Results of Serial Systolic Blood Pressure Determinations in 72 Normal* Women and 72 Subjects who Deieloped Pregnancy-Induced Hypertension

\begin{tabular}{|c|c|c|c|c|c|c|c|}
\hline \multicolumn{4}{|c|}{ Patients who remained normal } & \multicolumn{4}{|c|}{$\begin{array}{l}\text { Patients who developed pregnancy- } \\
\text { induced hypertension }\end{array}$} \\
\hline \multirow{2}{*}{$\frac{\begin{array}{c}\text { Wk of } \\
\text { pregnancy }\end{array}}{7-10}$} & \multirow{2}{*}{$\begin{array}{c}\begin{array}{c}\text { Number } \\
\text { of } \\
\text { studies }\end{array} \\
3\end{array}$} & \multicolumn{2}{|c|}{ Mean \pm SEM } & \multirow{2}{*}{$\begin{array}{c}\begin{array}{c}\text { Number } \\
\text { of } \\
\text { studies }\end{array} \\
10\end{array}$} & \multirow{2}{*}{$\frac{\text { Mean }}{106.8}$} & \multirow{2}{*}{$\frac{\text { SEM }}{4.9}$} & \multirow{2}{*}{$\frac{P}{\mathrm{NS}}$} \\
\hline & & 106.7 & 8.8 & & & & \\
\hline $11-14$ & 13 & 100.2 & 2.3 & 25 & 100.8 & 2.0 & NS \\
\hline $15-18$ & 36 & 95.9 & 1.7 & 33 & 102.3 & 1.9 & $<0.01$ \\
\hline $19-22$ & 48 & 95.3 & 1.3 & 50 & 99.2 & 1.5 & $<0.05$ \\
\hline $23-26$ & 49 & 99.3 & 1.7 & 51 & 99.6 & 1.2 & NS \\
\hline $27-28$ & 34 & 98.8 & 1.8 & 37 & 101.4 & 1.9 & NS \\
\hline $29-30$ & 38 & 99.5 & 1.5 & 34 & 103 & 2.2 & NS \\
\hline $31-32$ & 51 & 97.6 & 1.3 & 44 & 106.8 & 1.6 & $<0.01$ \\
\hline $33-34$ & 40 & 99.4 & 1.6 & 37 & 103.3 & 1.8 & NS \\
\hline $35-36$ & 55 & 100.9 & 1.6 & 43 & 107.0 & 1.6 & $<0.01$ \\
\hline $37-38$ & 58 & 101.3 & 1.5 & 28 & 110.8 & 2.4 & $<0.01$ \\
\hline $39-40$ & 63 & 104.6 & 2.0 & $20 \ddagger$ & 113.3 & 2.7 & $<0.05$ \\
\hline
\end{tabular}

* The results obtained from the first 72 patients who remained normotensive are contrasted to the results obtained from the 72 patients who became hypertensive. $\ddagger$ These 20 determinations were obtained before the development of hypertension $(140 / 90)$. All subjects became overtly hypertensive by delivery. 


\begin{tabular}{|c|c|c|c|c|c|c|c|}
\hline \multirow{3}{*}{$\frac{\begin{array}{c}\text { Wk of } \\
\text { pregnancy }\end{array}}{7-10}$} & \multicolumn{3}{|c|}{ Normal } & \multicolumn{4}{|c|}{ Pregnancy-induced hypertension } \\
\hline & $\begin{array}{c}\text { Number } \\
\text { of } \\
\text { studies }\end{array}$ & \multicolumn{2}{|c|}{ Mean \pm SEM } & \multirow{2}{*}{$\begin{array}{c}\begin{array}{c}\text { Number } \\
\text { of } \\
\text { studies }\end{array} \\
10\end{array}$} & \multirow{2}{*}{$\begin{array}{r}\text { Mean } \\
52.0\end{array}$} & \multirow{2}{*}{$\frac{ \pm \mathrm{SEM}}{3.5}$} & \multirow{2}{*}{$\frac{P}{\mathrm{NS}}$} \\
\hline & 3 & 60.7 & 2.9 & & & & \\
\hline $11-14$ & 13 & 54.6 & 2.6 & 25 & 52.7 & 1.9 & NS \\
\hline $15-18$ & 36 & 50.4 & 1.8 & 33 & 51.2 & 1.8 & NS \\
\hline $19-22$ & 48 & 50.8 & 1.3 & 50 & 50.4 & 1.5 & NS \\
\hline $23-26$ & 49 & 52.8 & 1.5 & 51 & 53.4 & 1.3 & NS \\
\hline $27-28$ & 34 & 54.2 & 1.9 & 37 & 55.3 & 1.9 & NS \\
\hline $29-30$ & 38 & 51.9 & 1.7 & 34 & 56.9 & 2.0 & NS \\
\hline $31-32$ & 51 & 53.8 & 1.6 & 44 & 58.9 & 1.9 & $<0.05$ \\
\hline $33-34$ & 40 & 55.2 & 1.7 & 37 & 60.0 & 2.0 & NS \\
\hline $35-36$ & 55 & 56.9 & 1.5 & 43 & 63.7 & 1.9 & $<0.01$ \\
\hline $37-38$ & 58 & 58.1 & 1.5 & 28 & 62.9 & 2.5 & NS \\
\hline $39-40$ & 63 & 60.5 & 1.9 & $20 \ddagger$ & 63.7 & 1.7 & NS \\
\hline
\end{tabular}

* The results obtained from the first 72 patients who remained normotensive are contrasted to the results obtained from the 72 patients who became hypertensive. $\ddagger$ These 20 determinations were obtained before the development of hypertension (140/90). All subjects became overtly hypertensive by delivery.

ment of proteinuria was a late and inconsistant feature confined to women who had already become hypertensive.

There was no laboratory evidence in any of these subjects of impaired renal function. Even during the acute phase of hypertension, no patient had plasma urea nitrogen values above $12 \mathrm{mg} \%$.

Four subjects who later developed hypertension remained resistant to angiotensin, that is they required more than $8 \mathrm{ng} / \mathrm{kg} / \mathrm{min}$ of A-II to elicit a pressor response throughout pregnancy. Such a pattern has been observed previously in two primigravid patients with chronic hypertension. Only longer follow-up of these four patients may reveal whether they too are suffering from chronic hypertension rather than pregancy-induced hypertension.

One patient has been followed through two pregnancies. The results in this subject, J. D. R., are shown in Tables VI and VII. ${ }^{5}$ During her first pregnancy, the patient became sensitive to A-II, requiring less than $8 \mathrm{ng} /$ $\mathrm{kg} / \mathrm{min}$, by the 31 st wk of pregnancy, and this sensitivity persisted (Table VII). Through wk 35, the patient was normotensive, without edema or proteinuria. 6 days later, the patient was hospitalized with hypertension (150/

\footnotetext{
${ }^{5}$ Tables VI and VII contain the results of each angiotesin infusion related to gestation and to each individual patient in both normal and abnormal groups, respectively. However, because of the extremely large size of these tables. they have been deposited in the National Auxiliary Publications Service, ASIS/NAPS, c/o Microfiche Publications, New York. The account number is 02156.
}

110 ), edema of the extremities, and total placental abruption, and delivered a $4 \mathrm{lb} .11 \mathrm{oz}$. stillborn infant. During her second pregnancy, the patient remained normotensive and resistant to A-II infusion (requiring more than 8 $\mathrm{ng} / \mathrm{kg} / \mathrm{min}$, Table VI), and delivered at term a healthy $7 \mathrm{lb} .4 \mathrm{oz}$. male infant.

One patient developed eclampsia. Her family history revealed that this 16-yr-old black patient was herself the product of a toxemic pregnancy. The doses of A-II required in this patient were $11.8 \mathrm{ng} / \mathrm{kg} / \mathrm{min}$ at $12 \mathrm{wk}$, 23.7 at $17 \mathrm{wk}, 16.4$ at $21 \mathrm{wk}$, and 22.7 at $25 \mathrm{wk}$. The patient was lost to follow-up until wk 36, when her dose requirement was $5.6 \mathrm{ng} / \mathrm{kg} / \mathrm{min}$. At this visit, there was no edema or proteinuria and the blood pressure was $110 / 70$. The patient was next seen 12 days later in active labor with a blood pressure of $170 / 120$ but without edema or proteinuria. She had a rapid labor and delivered a healthy $6 \mathrm{lb} .9 \mathrm{oz}$. infant. The delivery was without incident but approximately $90 \mathrm{~min}$ afterward the patient suffered a grand mal seizure. She made a complete recovery with return of her blood pressure to normal. Complete neurologic evaluation failed to reveal any organic nervous system disease. There was no previous history of seizures.

\section{DISCUSSION}

Throughout most of pregnancy, normal gravidas are remarkably resistant to the pressor effects of infused angiotensin II. The present study shows that the onset 
of this resistance is evident by 7-8 wk of pregnancy. The explanation for this early resistance to the pressor effects of A-II may be attributable to the increases in circulating A-II beginning at this early stage of pregnancy, as reported by Robertson, Weir, Düsterdieck, Fraser, and Tree (10). Several mechanisms have been postulated previously that would account for an increase in the release of renin by the juxtaglomerular apparatus of the maternal kidney early in pregnancy. These mechanisms include, $a$ ) the natriuretic effect of progesterone, $b$ ) the relaxing effect of progesterone on vascular smooth muscle, and $c$ ) the "shunting" of blood to the pelvic viscera. Coincident with the increase in angiotensin substrate as a result of the hyperestrogenic state of early pregnancy (7), an evident increase in A-II would then obtain. These changes, resulting in increased plasma A-II in early pregnancy, would create a physiologic state with respect to pressor responsiveness analogous to that whch Kaplan and Silah proposed for the resistance to A-II in nonpregnant subjects with high plasma renin activity (24). This hypothesis has found confirmation in the measurements of A-II levels in the plasma by Chinn and Düsterdieck (25).

That these systems, renin-angiotensin II-aldosterone, are operative at increased levels in early pregnancy is suggested by the findings of Scott, who has shown that plasma volume begins to increase in pregnancy as early as $6-8$ wk pregnancy and rises progressively thereafter until approximately $28-30 \mathrm{wk}$ of pregnancy, when the maximum plasma volume expansion is usually reached (26). It is interesting to note from the present study that in those gravidas who remained normotensive throughout pregnancy, a slight but continuing decrease in resistance to A-II pressor effects began at approximately 30 wk pregnancy, the same time that plasma volume reaches its maximal expansion. These corollaries may suggest that in normal pregnancy there is relative physiologic underfilling until approximately $30 \mathrm{wk}$ pregnancy. It should be emphasized, however, that even after maximal vollume expansion has occurred and a slight decrease in resistance is observed, normal gravidas remain markedly resistant to the pressor effects of A-II throughout the remainder of pregnancy. This would suggest that factors other than relative volume deficits may represent the principal determinants of A-II pressor responsiveness in pregnancy.

Alternative explanations for the early acquisition of angiontensin resistance in pregnant subjects may be attributable to the appearance of angiotensinase in these women. However, while controversy exists concerning the presence of increased angiotensinase in late pregnancy, Berger and Langhans (27) and Landesman, Biron, Castellanos, La Russa, and Wilson (28) agree that there is no increase of angiotensinase in early pregnancy at a time when maximum resistance to the A-II pressor effects are observed.

Yet a third explanation for the resistance of pregnant women to the pressor response may reside in the refractoriness of the arteriolar wall to A-II in these subjects. This explanation was previously suggested by Talledo, Chesley, and Zuspan (23) for pregnant subjects and by Brunner, Chang, Wallach, Sealey, and Laragh from experimental work in the rat (29). The observation that acute volume expansion in normotensive term pregnant subjects does not alter pressor response to A-II infusions despite a $35 \%$ decrease in plasma renin activity would suggest that the refractoriness of the arteriolar wall might be the major determinant of pressor responsiveness (30).

The pattern of pressor responses to A-II in those 72 primigravid subjects who ultimately developed pregnancy-induced hypertension differs markedly from that in those who remained normal. Several points are of particular interest. First, these subjects also became markedly resistant to the effects of A-II early in pregnancy. Their maximal resistance to A-II was achieved at $18 \mathrm{wk}$ of pregnancy. However, by $23-26 \mathrm{wk}$, while clinically normal, they became clearly defined as a separate group. At this early stage of gestation many of these subjects had become exquisitely sensitive to A-II in spite of the fact that they exhibited no clinical stigmata of pregnancy-induced hypertension (Fig. 2 . Tables IV and V). Therefore, in this group of subjects destined to develop hypertension, the declining resistance to the pressor effects of A-II occurred considerably before the time of expected maximal volume expansion and long before the development of hypertension. While the mechanism of decreasing resistance to A-II in this group of subjects is not defined by this study, the corollaries cited above would favor the proposition that the principal determinant was a decreased refractoriness of the arterioles of these subjects to A-II. Ames, Borkowski, Sicinski, and Laragh have reported an increasing vascular sensitivity with prolonged infusion of A-II in normal men (31). In this context, pregnancy-induced hypertension may represent a failure of physiologic adaptation to A-II that occurs in the vessels of those gravidas who remain normotensive. Under this circumstance, the production of renin by the uterus $(32,33)$, if it is physiologically active in pregnancy (34), and if its production is not subject to the same control mechanisms as that of renal origin $(35,36)$, would jeopardize to pregnancy-induced hypertension those gravidas who failed to develop or maintain vascular refractoriness during pregnancy.

The marked differences between the two groups of subjects by the 28th wk of pregnancy at a time when both groups are clinically normal, that is, normotensive and

Angiotensin II Pressor Effect in Pregnancy

2687 
without edema or proteinuria, suggests that a screening test at the beginning of the third trimester is feasible. Of the 120 subjects who remained normal, 103 had at least one infusion of A-II between the 28th and 32nd wk; $87 \%$ of them were resistant, in that they required more than $8 \mathrm{ng} / \mathrm{kg} / \mathrm{min}$ to elicit the pressor response in every study during that time (Table VI). That is, $87 \%$ of these young primigravid, predominantly Black, high-risk subjects did not develop hypertension. ${ }^{\circ}$

On the other hand, of the 72 subjects who ultimately developed pregnancy-induced hypertension, 50 were studied at least once during the 28-32nd-wk time period. $45(90 \%)$ had at least one study in which the pressor dose was less than $8 \mathrm{ng} / \mathrm{kg} / \mathrm{min}$ in each case.

During the 28-32nd-wk time period, 46 of the subjects who remained normotensive had two or more tests. Only one subject required less than $8 \mathrm{ng} / \mathrm{kg} / \mathrm{min}$ ( 5 and 7) in each study. During this same gestational time, 33 subjects who ultimately developed hypertension were studied on two or more occasions. Only one of these subjects required more than $8 \mathrm{ng} / \mathrm{kg} / \mathrm{min}$ on each of the pressor tests and in this subject in all three tests thereafter, the dose requirement was less than 8 $\mathrm{ng} / \mathrm{kg} / \mathrm{min}$.

If we consider these data, it is reasonable to assume that a high degree of predictability of the ultimate development of pregnancy-induced hypertension might be achieved with good pregnancy dating and if two or more tests were performed during the 28-32nd-wk period of time. It may be possible that the ability to predict continued normalcy may approach $100 \%$; the normals by definition being a homogeneous group that manifest early and continued vascular resistance to A-II. However, it is entirely possible that better predictability may not be possible within the group that develops hypertension than was achieved by this study. McCartney, for example, observed that the clinical diagnosis of preeclampsia when compared to renal biopsies in the same patients was confirmed in only 44 of 62 primigravid pregnancies $(71 \%)$, while the remaining pregnancy biopsies revealed 15 patients to have chronic renal disease $(24 \%)$ and three patients to have normal biopsies $(5 \%)$ (37). Certainly any clinical grouping of pregnancy-induced hypertension, even when restricted to young primigravid patients, will include an admixture of patients with labile hypertension or chronic renal disease.

The concept of a pressor substance being used to identify the patient at risk of developing pregnancyinduced hypertension is not new. Dieckman and Michel

\footnotetext{
${ }^{8}$ In this group of 103 who remained normal, 161 studies were performed between wk 28 and 32. A dose of more than $8 \mathrm{ng} / \mathrm{kg} / \mathrm{min}$ was required in 147 studies; $6-8 \mathrm{ng} / \mathrm{kg} /$ min in 9 studies and less than $6 \mathrm{ng} / \mathrm{kg} / \mathrm{min}$ in 5 instances.
}

(38) described an increased vascular sensitivity to posterior pituitary extracts in women with pregnancyinduced hypertension. Raab, Schroeder, Wagner, and Gigie (39), employing infusions of epinephrine and norepinephrine in a prospective study, demonstrated an increased vascular sensitivity to the pressor effects of these catecholamines in 17 of 100 women. However, only 10 of 17 women later developed pregnancy-induced hypertension; and of these 10, only 3 patients were primigravidas. In addition, the diagnostic criterion required to identify these patients was an increase in systolic blood pressure of greater than $60 \mathrm{~mm} \mathrm{Hg}$. This marked increase in blood pressure seems much too dangerous to be accepted at present.

The technique described in this report, utilizing A-II infusions is safe and appears to be highly selective. It also offers the possibility of patient selection for prospective studies of pregnancy-induced hypertension at a time when clinically evident disease and the ensuing physiologic and/or pathophysiologic consequences of the disease are not present. These late consequences may represent sequelae that may obscure the search for the etiology. Additionally, this technique offers a method for the early selection of patients who will receive close observation and form the basis for a group in which various treatment and preventive modalities may be evaluated.

\section{ACKNOWLEDGMENTS}

The authors are grateful to the Residents and Fellows of the Obstetrics and Gynecology Service of Parkland $\mathrm{Me}-$ morial Hospital for their invaluable cooperation. In addition we are indebted to Drs. Jack A. Pritchard and Leon C. Chesley for valuble guidance in the preparation of the manuscript.

This study was supported in part by a Fellowship Grant from the Lalor Foundation and by U.S.P.H.S. Grant USAM-06912.

\section{REFERENCES}

1. Boonshaft, B., J. M. B. O'Connell, J. M. Hayes, and G. E. Schreiner. 1968. Serum renin activity during normal pregnancy: effect of alterations of posture and sodium intake. J. Clin. Endocrinol. Metab. 28: 1641.

2. Brown, J. J., D. L. Davies, P. B. Doak, A. F. Lever, and J. I. S. Robertson. 1963. Plasma renin in normal pregnancy Lancet. 2: 900.

3. Brown, J. J., D. L. Davies, P. B. Doak, A. F. Lever, and J. I. S. Robertson. 1966. Serial estimation of plasma renin concentration during pregnancy and after parturition. J. Endocrinol. 35: 373 .

4. Fasciolo, J. C., E. DeVito, J. C. Romero, and J. N. Cucchi. 1964. The renin content of the blood of humans and dogs under several conditions. Can. Med. Assoc. J. 90: 206 .

5. Gordon, R. D., S. Parsons, and E. M. Symonds. 1969. A prospective study of plasma renin activity in normal and toxaemic pregnancy. Lancet. 1: 347. 
6. Gould, A. B., I. T. Skeggs, and J. K. Kahn. 1966. Measurement of renin and substrate concentrations in human serum. Lab. Invest. 15 : 1802.

7. Helmer, O. M., and W. E. Judson. 1967. Influence of high renin substrate levels on renin-angiotensin system in pregnancy. Am. J. Obstet. Gy'necol. 99: 9.

8. Pickens, P. T., F. M. Bumpus, A. M. Lloyd, R. R. Smeby, and I. H. Page. 1965. Measurement of renin activity in human plasma. Circ. Res. 17: 438.

9. Weir, R. J., D. B. Paintin, J. J. Brown, R. Fraser, A. F. Lever, J. I. S. Robertson, and J. Young. 1971. Serial study in pregnancy of the plasma concentrations of renin, corticosteroids, electrolytes and proteins and of hematocrit and plasma volume. J. Obstet. Gynaecol. Br. Commoniv. 78: 590.

10. Robertson, J. I. S., R. J. Weir, G. O. Düsterdieck, R. Fraser, and M. Tree. 1971. Renin, angiotensin and aldosterone in human pregnancy and the mentrual cycle. Scott. Med. J. 16: 183.

11. Massani, Z. M., R. Sanguinetti, R. Gallegos, and D. Raimondi. 1967. Angiotensin blood levels in normal and toxemic pregnancies. Am. J. Obstet. Gynecol. 99: 313.

12. Jones, K. M., R. Lloyd-Jones, A. Riondel, J. F. Tait, S. A. S. Tait, R. D. Bulbrook, and F. C. Greenwood. 1959. Aldosterone secretion and metabolism in normal men and women and in pregnancy. Acta Endocrinol. 30: 321.

13. Kumar, D., L. A. W. Feltham, and A. G. Gornall. 1959. Aldosterone excretion and tissue electrolytes in normal pregnancy and preeclampsia. Lancet. 1: 541.

14. Rinsler, M. G., and B. Rigby. 1957. Function of aldosterone in the metabolism of sodium and water in pregnancy. Br. Med. J. 2: 966.

15. Sims, E. A. H., C. I. Meeker, M. J. Gray, M. Watanabe, and S. Solomon. 1964. The secretion of aldosterone in normal pregnancy and in preeclampsia. Aldosterone Symp. 1: 499.

16. Tait, J. F., and B. Little. 1968. The metabolism of orally and intravenously administered labeled aldosterone in pregnancy subjects. J. Clin. Invest. 47: 2423.

17. Venning, E. H., and I. Dyrenfurth. 1956. Aldosterone excretion in pregnancy. J. Endocrinol. Metab. 16: 426.

18. Watanabe, M., C. I. Meeker, M. J. Gray, E. A. H. Sims, and S. Solomon. 1963. Secretion rate of aldosterone in normal pregnancy. J. Clin. Invest. 42: 1619.

19. Abdul-Karim, R., and N. S. Assali. 1961. Pressor response to angiotonin in pregnant and nonpregnant women. Am. J. Obstet. Gy'necol. 82: 246

20. Chesley, L. C. 1966. Vascular reactivity in normal and toxemic pregnancy. Clin. Obstet. Gy'necol. 9: 871.

21. Brown, J. J., D. L. Davies, P. B. Doak, A. F. Lever, J. I. S. Robertson, and P. Trust. 1965. Plasma renin concentration in hypertensive disease of pregnancy. Lancet. 2: 1219.

22. Brown, J. J., D. L. Davies, P. B. Doak, A. F. Lever, and J. I. S. Robertson. 1966. Plasma renin concentration in the hypertensive diseases of pregnancy. J. Obstet. Ginaccol. Br. Commoniv. 73: 410.

23. Talledo, O. E., L. C. Chesley, and F. P. Zuspan. 1968. Renin, angiotensin system in normal and toxemic pregnancies. III. Differential sensitivity to angiotensin II and norepinephrine in toxemia of pregnancy. Am. J. Obstct. Gynecol. $100: 218$.

24. Kaplan, N. M., and J. G. Silah. 1964. The effect of angiotensin II on the blood pressure in humans with hypertensive disease. J. Clin. Invest. 43: 659.

25. Chinn, R. H., and G. Düsterdieck. 1972. The response of blood pressure to infusions of angiotensin II: relation to plasma concentrations of renin and angiotensin II. Clin. Sci. 42: 489 .

26. Scott, D. E. 1972. Anemia in pregnancy. In Obstetrics and Gynecology Annual. Ralph M. Wynn, editor. Appleton-Century-Crofts Inc., New York. 1972 edition. 219.

27. Berger, M., and J. Langhans. 1967. Angiotensinase activity in pregnant and nonpregnant women. Am. J. Obstct. Gynecol. $98: 215$.

28. Landesman, R., P. Biron, R. Castellanos, R. La Russa, and K. H. Wilson. 1963. Plasma angiotensinase activity in normal and toxemic pregnancy. Obstet. Gynecol. 22: 316.

29. Brunner, H. R., P. Chang, R. Wallach, J. E. Sealey, and J. H. Laragh. 1972. Angiotensin II vascular receptors: their avidity in relationship to sodium balance, the autonomic nervous system, and hypertension. J. Clin. Invest. $51: 58$.

30. Gant, N. F., P. J. Whalley, P. K. Siiteri, and P. C. MacDonald. 1972. The nature of the angiotensin responsiveness in normal and toxemic pregnancy. Program of the Society for Gynecologic Investigation, 19th meeting, The Society for Gynecologic Investigation, San Francisco. (Abstr.) 30.

31. Ames, R. P., A. J. Borkowski, A. M. Sicinski, and J. H. Laragh. 1965. Prolonged infusions of angiotensin II and norepinephrine and blood pressure, electrolyte balance, and aldosterone, and cortisol secretion in normal man and in cirrhosis with ascites. J. Clin. Inc'est. 44: 1171 .

32. Symonds, E. M., M. A. Stanley, and S. L. Skinner. 1968. Production of renin by in vitro cultures of human chorion and uterine muscle. Nature (Lond.). 217: 1152.

33. Symonds, E. M., S. L. Skinner, M. A. Stanley, J. A Kirkland, and R. C. Ellis. 1970. An investigation of the cellular source of renin in human chorion. J. Obstet. Gynaecol. Br. Commonze. 77 : 885.

34. Skinner, S. L., E. R. Lumbers, and E. M. Symonds. 1972. Analysis of changes in the renin-angiotensin system during pregnancy. Clin. Sci. 42: 479.

35. Carretero, O. A., and J. A. Houle. 1970. A comparison of renin obtained from pregnant uterus and kidney of the dog. Am. J. Physiol. 218: 689.

36. Ferris, T. F., J. H. Stein, and J. Kaufman. 1972. Uterine blood flow and uterine renin secretion. J. Clin. Invest. $51: 2827$

37. McCartney, C. P. 1964. Pathological anatomy of acute hypertension of pregnancy. Circ. Suppl. 29-30: 37.

38. Dieckmann, W. J., and H. L. Michel. 1937. Vascularrenal effects of posterior pituitary extracts in pregnant women. Am. J. Obstct. Gynccol. 33: 131.

39. Raab, W., G. Schroeder, R. Wagner, and W. Gigie. 1956. Vascular reactivity and electrolytes in normal and toxemic pregnancy. J. Clin. Endocrinol. Metab. 16: 1196. 